Piotr Krajewski*

Olsztyn

\title{
Syndrom Geppetto. Ewolucja pojmowania rodzicielstwa w społeczeństwach ekonomicznie zaawansowanych
}

Pośród wielu przemian kulturowych, jakie dokonały się w ostatnich dziesięcioleciach - choć niezwykle radykalna - jedna wydaje się mniej zauważalna od pozostałych, a dotyczy ona rodzicielstwa i jego egzystencjalnego znaczenia. Dopiero w ostatnich latach dostrzeżono drastyczne zmiany, które są konsekwencją znanych już wszystkim ogromnych postępów w badaniach nad biotechnologiami reprodukcji życia. Ich efektem są zmiany zachowań społecznych i modyfikacje powszechnego wyobrażenia i rozumienia zjawiska przekazywania życia ${ }^{1}$.

Pojawienie się ,dzieci z probówki” zrodziło równie nowe co niepokojące wyobrażenia, jakie człowiek łączy z własną płodnością, implikacjami związanymi z rodzicielstwem oraz tożsamością osobową i społeczną mężczyzn i kobiet² ${ }^{2}$. We wszystkich przypadkach biotechnologicznego ,projektowania” rodzicielstwa ${ }^{3}$ wydaje się, że to właśnie egzystencjalne i etyczne znaczenie własnej płodności, a nie wyrafinowane możliwości biotechnologii determinują kontrowersyjność zjawisk naszych czasów,

* Dr Piotr Krajewski jest pracownikiem Uniwersytetu Warmińsko-Mazurskiego w Olsztynie.

${ }^{1}$ Cfr. M. Paolinelli, Natura umana e persona umana: la dignità delia procreazione. II fascino deliatecnica e la domanda umana, w: E. Sgreccia (red.), II dono delia vita, Milano 1987, s. 73-90; M. Lombardi Ricci, Lafecondazione eterologa, Rivista di teologia morale 146 (2005), s.183-190.

2 Cfr. M. Brancatisano, Paternita e Maternità: valore umano e cristiano, Familia et Vita 4 (1999), 2-3, s. 131-134; B. Kurdybacha, Człowiek istota seksualnq, Paedagogia Christiana 2/2005, s. 55-72; D. Pauluk, Kobieta w polskiej tradycji zycia rodzinnego i społecznego, Paedagogia Christiana 2/2005, s. 213-225.

${ }^{3}$ Cfr. M. Machinek, Życie w dyspozycji człowieka. Wybrane problemy etyczne u poczatku ludzkiego życia, Olsztyn 2004, s. 118-135. 
takich jak np.: macierzyństwo zastępcze (surrogate mother)4, odstępowanie oocytów, zamrażanie spermy osób zmarłych, banki nasienia geniuszy, matki po sześćdziesiątce, klonowanie i eksperymenty przypominające science fiction. Wszystkie te działania łączy jeden element: osobista chęć rodzica (lub rodziców) do kontrolowania życia, do „stworzenia” sobie dziecka na zamówienie.

\section{Rodzice biologiczni, naturalni i prawni}

Nasza zachodnia kultura i tradycja prawnicza dotychczas precyzyjnie odróżniała instytucję rodzica biologicznego od prawnego, uznając prymat tego pierwszego. Stwierdzenie jego osoby wciąż stanowi jedną z zasad prawa, decydujących o tożsamości społecznej nowo narodzonego 5 .

Pomimo że rodzicielstwo prawne jest determinantą sytuacji prawnej podmiotu, prawo i zwyczaje opierają się na założeniu pokrywania się rodzicielstwa prawnego i biologicznego, z wyjątkiem adopcji. Jednakże prymat prawny i moralny rodzicielstwa biologicznego jest w rzeczywistości potwierdzany we wszystkich tych przypadkach, w których trybunał anuluje decyzje o adopcji, przyznając rodzicom biologicznym większe prawa do ich własnych dzieci. Aktualne normatywy dotyczące adopcji, pomimo iż bardziej nastawione są na zapewnienie dziecku odpowiednich warunków wychowania niż zapewnienie rodzinie spadkobiercy (zasada dominująca w przeszłości), w zasadzie nie przekreślaj ą łączności dziecka z jego biologiczna rodzina.

Dominująca obecnie praktyka adopcji i polityka świadczeń społecznych, mające na celu zapewnienie opieki nieletnim, nastawione są na zapewnienie wsparcia rodzinie będącej w potrzebie, aby pomóc jej wykształcić i wychować własne dzieci. Żyjemy więc w kulturze, w której również prawo pozytywne dostrzega wyższość „naturalnego” rodzicielstwa $\mathrm{w}$ porównaniu z jakimikolwiek sposobami instytucjonalnymi, skierowanymi na opiekę nieletnich. Prawo i kultura w sprawach struktury rodziny i wychowania dzieci często powołują się na termin „naturalność”, używając go jako modelu i idealnego punktu odniesienia. Jest to oczywiste, ponieważ „naturalny” model rodzicielstwa pokrywał się z rodzicielstwem biologicznym. Pomimo licznych przykładów, iż tak nie jest, nadal spotykamy się z przeświadczeniem, że rodzice biologiczni są zawsze i w każdym wypadku najlepszymi opiekunami swoich dzieci.

Pojawienie się biotechnologii $\mathrm{w}$ badaniach nad prokreacją $\mathrm{w}$ pierwszym rzędzie zadecydowało jednocześnie o podziale na to, co „naturalne” i na to, co biologiczne oraz naruszyło dotychczasowe znaczenie rodzicielstwa biologicznego jako rodzicielstwa „naturalnego”. Odnosi się to nie tylko do samych metod, które nie mają nic wspólne-

${ }^{4}$ Cfr. M. L. Di Pietro, Fecondazione artiflciale e frammentazione delia maternità, La Famiglia 154/1992, s. 5-19.

${ }^{5}$ Cfr. J. L. Tauran, I diritti dell'uomo e la difesa giuridica delia famiglia, Familia et Vita 4/1991, s. 50-57; M. Salvi, Paradossi biotecnologici: identita personale e genetica applicata, Bioetica 2/1997, s. 171-192. 
go z naturalnością, ale w ich świetle również pojęcie biologicznego ojca i biologicznej matki odnosi się do czegoś całkiem odmiennego niż to, co zawsze określano tym terminem.

Sześćdziesięciolatka, która rodzi dziecko dzięki komórce jajowej innej kobiety, nie jest „matką biologiczną” i wątpliwe jest również, aby mogła być określana „,matką naturalną". A czy kobieta, która wypożycza swoją macicę do implantacji embrionu uzyskanego z nasienia i oocytu pary zamawiającej, jest „matką naturalną”? W jaki sposób zdefiniować jako rodziców biologicznych dawców komórek jajowych i nasienia? ${ }^{7} \mathrm{~W}$ jaki sposób martwy mężczyzna, którego zamrożona sperma została użyta przez jego owdowiałą żonę do urodzenia dziecka może być uznany za prawnego i biologicznego ojca nowo narodzonego?

Wprowadzenie technik, które naruszają zasadę pewności rodzicielstwa biologicznego (obcy embrion donoszony przez inną kobietę), prowadzi w pierwszym rzędzie do przewagi i nieodwołalności rodzicielstwa prawnego. Tego rodzaju przypadki ukazują jednak całkowitą nienaturalność tego rodzaju kontraktu, którego z kilku przyczyn nie można uznać za dopuszczalny: rodząca, która „wypożycza” swój układ rozrodczy, z pewnością może traktować wydawane na świat dziecko jako swoje, a odczuwane trudy ciąży, bóle porodowe i sam poród jako źródło „naturalnej” więzi między nią a dzieckiem znacznie silniejsze niż poczucie zobowiązania, wynikające z zawartego kontraktu i uzyskanej zań sumy. W tej perspektywie w świadomości ciężarnej pochodzenie biologiczne embrionu wydaje się schodzić na dalszy plan. Kierując się tą samą logiką, również sześćdziesięcioletnie matki mogą nie przejmować się biologicznym pochodzeniem uzyskanej komórki jajowej. W ten sposób mamy tu matki naturalne, ale nie biologiczne oraz biologicznych ojców i matki (dawców), lecz nie naturalnych, którzy mogą być przecież całkowicie nieznani dzieciom, kobietom noszącym płód i rodzącym, a nawet samym sobie. W tym miejscu w poważnym stopniu naruszone zostają prawa dziecka do wiedzy o sobie i swoich rodzicach, o swoim pochodzeniu i tożsamości ${ }^{8}$.

\section{Symbolika rodzicielstwa biologicznego}

Nie ma powodu, aby sądzić, że dzisiejsza kultura osłabiła lub odeszła od przypisywania szczególnego znaczenie pochodzeniu biologicznemu danej osoby. Ogromna symboliczna wartość ojcostwa i macierzyństwa biologicznego we współczesnej kulturze wcale tak bardzo nie osłabła, a może nawet wzrosła. Można wręcz zaobserwować, że symboliczna wartość tego, co biologiczne przewyższa to, co naturalne

${ }^{6}$ Cfr. E. Sgreccia, Manuale di bioetica, t. 1, Milano 1988, s. 473-475.

${ }^{7} \mathrm{~W}$ przypadku, gdy chodzi o gamety, trudno nawet odwoływać się do terminu „darowizna” w znaczeniu miłosierdzie-solidarność, tak jak w przypadku darowania organów lub krwi. Przy transplantacji nerki lub transfuzji krwi nie narusza się niczyjej jedności ani nie daje się życia nowej istocie ludzkiej.

${ }^{8}$ Cfr. M. Lombardi Ricci, dz. cyt. 
w przypadku, gdy znaczenie tych dwóch określeń okazuje się odmienne. Paradoksem wydaje się, że ugruntowywanie prymatu tego, co biologiczne, występuje właśnie w naszej kulturze, kiedy to praktyki adopcji międzynarodowej i rozprzestrzenianie się adopcji jako takiej wydają się ujawniać nową i bardziej dojrzałą świadomość społeczną w stosunku do zadań rodziny. W ten sposób podkreśla się znaczenie etyki i uczuciowości w tworzeniu rodziny opartej nie tylko na więzi między małżonkami, ale na akceptacji życia dziecka9 (jakkolwiek i gdziekolwiek biologicznie poczętego, niezależnie od różnic etnicznych czy koloru skóry). Taka jest właśnie logika adopcji (również międzynarodowych) i zasada inspirująca ustawodawstwa wielu państw; pojawiają się tam normy zapewniające przede wszystkim rodzinę dziecku, które zostało jej pozbawione ${ }^{10}$.

W ten sposób dyspozycyjność przyszłościowych biotechnologii pokazuje przeciwstawne tendencje, potwierdzając pierwszeństwo tego, co biologiczne, tj. „więzów krwi" w kreowaniu nowego rodzaju rodzicielstwa w stosunku do prawa, etyki, a nawet w stosunku do natury. Od tej strony projektowane rodzicielstwo stanowi subtelną formę bałwochwalstwa. W planowaniu własnej reprodukcji ${ }^{11}$ biologicznej, bez uwzględniania innych zasad, które nie wiążą się z własnym projektem lub pragnieniem, człowiek jawi się sobie samemu jako Bóg, łudząc się, że przynajmniej prowizorycznie pokonał własną śmierć (lub śmierć drugiej osoby). Jest to jedynie antyczne i powracające pragnienie człowieka przedłużenia (w potomstwie) własnego istnienia, które dziś znajduje nowe sposoby realizacji.

\section{Społeczne przyzwolenie na wykorzystanie biotechnologii}

Podczas gdy nowe zasady rodzicielstwa zmieniają wszystkie nasze tradycyjne normy w tym zakresie i oddzielają biologiczność od naturalności, paradoksalnie nie wydaje się, abyśmy mieli do czynienia ze społeczną negacją konieczności podejmowania tego rodzaju decyzji, które pomimo polemik i dyskusji wydają się tolerowane i często akceptowane, przynajmniej przez pewną część społeczeństwa.

Uważa się, że tak bardzo upragnione, z taką determinacją oczekiwane dziecko, które pojawia się po tylu wyrzeczeniach związanych z podjętymi praktykami biotechnologicznymi, powinno być nad wyraz kochane. Akcentuje się to specjalnie, przypominając, że wiele dzieci poczętych i urodzonych w sposób bardziej „naturalny” i „spontaniczny” jest potem zaniedbywanych i porzucanych. W ten sposób kształtuje się opinię publiczną, podkreślając znaczenie wyższego poziomu życia, które można

\footnotetext{
${ }^{9}$ Cfr. M. Brancatisano, Paternità e Maternità: valore umano e cristiano, Familia et Vita 4 (1999) 2-3, s. 131-134.

${ }^{10}$ Cfr. S. E. R. Mons, J. L. Tauran, J diritti dell'uomo e la difesa giuridica delia famiglia, Familia et Vita 4 (1999) 1, s. 50-57.

${ }^{11}$ Podczas gdy termin ,prokreacja” wskazuje na współstwarzanie nowych ludzi, „,reprodukcja” kojarzysię z technicyzacją i ingerowaniem w proces przekazywania życia. Cfr. M. Machinek, dz. cyt., s. 81 .
} 
zapewnić poprzez racjonalne planowanie rodziny, również dzięki rozwijającym się naukom biomedycznym. Opinia publiczna skłonna jest w każdym razie do pobłażliwej akceptacji (również wtedy, gdy jest wstrząśnięta lub zakłopotana) wszystkich form programowanego rodzicielstwa, tak jakby sama chęć przekazywania życia za każdą cenę miała własne, wewnętrznie uzasadnienie etyczne, blokujące społeczną stygmatyzację. Taka postawa wydaje się paradoksalna również z tego powodu, że ta sama (pracująca nad doskonaleniem metod tworzenia życia) wspólnota społeczna jednocześnie dąży do pobłażania praktykom aborcyjnym. W rzeczywistości paradoks jest jedynie pozorny, ponieważ w praktyce zezwala się na praktyki aborcyjne $\mathrm{z}$ tych samych względów, które otwierają możliwość „projektowanych” ciąż, realizowanych z pomocą futurystycznych biotechnologii. Wynika to z przyznanego jednostce prawa do planowania lub odrzucenia własnego rodzicielstwa przy pełnej i całkowitej autonomii moralnej - dobro społeczne, w tym akurat wypadku, schodzi na drugi plan.

Prawo do bycia rodzicem w swej doniosłości wydaje się być w rzeczywistości upodobnione do niezbywalnych praw personalnych jednostki, tak jak np. prawo do życia, do wolności i do bycia szczęśliwym, usankcjonowane już Deklaracją Niepodległości USA z 1776 roku. Tylko w tej perspektywie można tłumaczyć żądania par homoseksualnych o uzyskanie praw do adopcji lub posiadania własnego dziecka.

Pojawia się więc pytanie: Czy prawo do bycia rodzicem jest rzeczywiście niezbywalnym prawem osoby ludzkiej? Jeżeli tak, to jak należy je rozumieć?

W historycznych doświadczeniach ludzkości, przynajmniej do niedawna, rodzicielstwo współistniało i pokrywało się z funkcją „reprodukcji” i „reprodukowania” (w sensie biologicznym, psychologicznym i społecznym) oraz wolą przyjmowania rodzącego się życia, a następnie dbałością o wychowanie dziecka. W tych dwóch współzależnych od siebie wymiarach również dostrzega się pewną kontrowersję, ponieważ rodzicielstwo uruchamia dynamikę reprodukcyjną, która nie jest czystą reprodukcją rodzica ani rodziców, a w konsekwencji również podzielanej przez nich kultury społecznej. Właśnie ta złożona dynamika umożliwia realizację procesu wychowawczego, w którym relacja rodzic-dziecko jest jednym z podstawowych komponentów. Zwyczaj i prawo regulujące związek małżeński i strukturę rodziny historycznie wywodzą się z uznania nierozerwalności funkcji reprodukcyjnych i opieki nad potomstwem przez dwa współodpowiedzialne podmioty ludzkie ${ }^{12}$.

$\mathrm{Z}$ pedagogicznego punktu widzenia istnieje wręcz potrzeba zagwarantowania warunków rozwoju nowo narodzonym, co wymaga stabilności struktury rodzinnej. Ale jeżeli rodzicielstwo rozumiane jako zdolność roztoczenia opieki nad rodzącym się życiem, stanowić by miało niezbywalne prawo podmiotowe jednostki, a nie dwojga rodziców, mielibyśmy do czynienia z potrzebą uznania przede wszystkim indywidualnego prawa do opieki, odpowiedzialności za życie jednostki niedojrzałej, bycia rodzicem, bez wpływu społeczeństwa na jego realizację i warunki egzystencjalne. Taka perspektywa uprawniałaby na przykład do adopcji przez osoby samotne

${ }^{12}$ Cfr. Centro Internazionale di Preparazione al Matrimonio, L'amore si costruisce. Difficoltà e gioie di essere figli, fidanzati, genitori, Milano 1994, s. 167-168. 
lub pary homoseksualne. a może chodzi tu o uznanie niezbywalnego prawa podmiotowego do „reprodukowania się” dla każdego człowieka? Takie prawo dopuszczałoby możliwość kontrolowania poczętego i biologicznie urodzonego (bez względu na rodzaj wsparcia biotechnologicznego lub dawców) życia ludzkiego przez kobietę lub mężczyznę.

Czy to możliwe, że istnieje takie absolutne prawo, dla którego realizacji od strony biologicznej i naturalnej, bezwzględnie wymagane jest współdziałanie obydwu płci? To podstawowy element głębokiej natury pragnienia rodzicielstwa, który pobudza do działania kobiety i mężczyzn uciekających się do biotechnologicznych praktyk wspomaganej rozrodczości. Wiadomo skądinąd, że większość z tych osób to pary heteroseksualne, niewielki odsetek stanowią osoby samotne, a minimalny - homoseksualiści.

W rzeczywistości wszystkie małżeństwa, które mogą mieć dzieci, również dzięki pomocy nowoczesnej medycyny, zazwyczaj nie muszą uciekać się do biotechnologicznych metod sztucznego zapłodnienia ani oocytów lub spermy pochodzących od osób trzecich. Tej nadzwyczajnej pomocy zwykle potrzebują pary, w których przynajmniej jedno $\mathrm{z}$ dwojga jest $\mathrm{z}$ różnych powodów niepłodne $\mathrm{z}$ powodu niezgodności antygenów, wieku lub w ogóle niemożliwości przekazania życia.

Oczywiście z taką niemożliwością mamy do czynienia w przypadku wszystkich pragnących zostać rodzicem bez partnera lub par homoseksualnych. W tych wszystkich przypadkach podmiot, za zgodą lub bez zgody drugiej strony, odwołuje się do indywidualnego, a nie podzielanego $\mathrm{z}$ drugą stroną prawa do bycia rodzicem; do prawa w żaden sposób już nie implikującego wspólnej odpowiedzialności. Jeżeli założymy istnienie prawa do indywidualnego rodzicielstwa w sposób nierozerwalny związanego $\mathrm{z}$ osobą ludzka, to $\mathrm{w}$ takim razie jak powinno wyglądać prawo obojga rodziców biologicznych? Dlaczego kobiety miałyby mieć większe prawo od mężczyzn w decydowaniu o aborcji lub życiu płodu? Czy protesty ojców przeciw decyzji usunięcia ciąży przez matki naprawdę pozbawione są jakiejkolwiek logiki lub podstaw prawnych?

\section{Kobiece wyobrażenie o macierzyństwie}

Trzeba powiedzieć, że obecne prawo, przypisujące kobiecie pierwszeństwo decydowania o życiu płodu w niej poczętego, ma swoje podstawy w doświadczeniach macierzyństwa „naturalnego”, tj. takiego, w którym biologiczne pochodzenie komórki jajowej i rozwój płodu dokonują się w tym samym organizmie.

Idea „podwójnego" macierzyństwa biologicznego (pierwsze to dostarczenie oocytu, drugie to ciąża, a następnie poród), a, co więcej, różnego z punktu widzenia prawa, była nie do pomyślenia ze względu na doświadczenia naturalne. Doświadczenia, w których prawa matki do opieki nad dziećmi i moralna godność pełnionej przez nią funkcji (pod pewnymi względami uważana za ważniejszą od ojcowskiej) zawsze były bardziej wiązane z ciążą i porodem niż z samym aktem poczęcia. 
Pomijając historyczną koncepcję kobiecej płodności, przypisującej kobiecie jedynie funkcję „,goszczenia” poczętego dziecka (biorąc pod uwagę ograniczoną wiedzę biologiczną i absolutne ignorowanie istnienia żeńskiego „czynnika rozrodczego"), sam fakt noszenia rozwijającego się dziecka pozostaje jednym z podstawowych elementów rodzicielstwa kobiety; elementem przesądzającym o macierzyńskich doświadczeniach i symbolem własnej płodności.

Symbolika i przeżycia związane z posiadaniem dziecka w psychice kobiety ściśle łączą się z ciążą. W stosunku do fizjologicznego zjawiska ciąży, a następnie samego porodu, biologiczne pochodzenie oocytu z pewnością schodzi na drugi plan w kształtowaniu się obrazu i konotacji płodności kobiety. Bolesne i tragiczne doświadczenie aborcji (nawet jeżeli jest ona chciana) jest całkowicie odmienne i różni się od niepowodzenia sztucznego zapłodnienia albo uśmiercenia zamrożonego embrionu.

Psychologiczna tożsamość kobiety składa się ze skomplikowanego układu symboliki ${ }^{13}$, ściśle związanej właśnie z doświadczeniami porodu i aborcji, odrzucenia pokusy tego rodzaju doświadczeń lub ich braku. Tak więc dla kobiety macierzyństwo to przede wszystkim ciąża i jej rozwiązanie, a nie deponowanie lub przekazanie komórek rozrodczych. To wszystko pokazuje, jak głęboko współczesna biotechnologia zmienia wyobrażenie i tożsamość kobiety i mężczyzny, którą w sobie noszą i której doszukują się u współmałżonka lub partnera. Pod tym względem my wszyscy jesteśmy psychologicznie zagrożeni, nawet jeżeli bardziej lub mniej ostro dostrzegamy to zjawisko w zamieszaniu, wywoływanym biotechnologiami, zmieniającymi nasze wyobrażenie o życiu, wieku, płci i oczywiście rodzicielstwie ${ }^{14}$.

\section{Obiektywizm etyczny i rodzicielstwo}

Obecny system prawny i praktyka generalnie pozwalają zarówno na całkowitą arbitralność rodzica co do planowego „fabrykowania” dziecka, czy też aborcji i przyznaje to prawo pojedynczemu podmiotowi (w zależności od przypadku, mężczyźnie lub kobiecie), a nie zainteresowanej parze. Dostrzega się w tym, zwarty w swej logice, rozwój indywidualizmu etycznego, który w formie współczesnego Oświecenia budowany jest na osiaggnięciach nauk biologicznych i zmieniających się zachowaniach społecznych. Dziwi tylko, że nie zauważa się oczywistej sprzeczności w funkcjonowaniu tej zasady. Nikomu nie przychodzi na myśl protestować, że uznanie prawa jednostki do rodzicielstwa $\mathrm{w}$ sensie biologicznego manipulowania życiem, w rzeczywistości stoi w sprzeczności z podmiotowym prawem do istnienia osoby niedojrzałej. Embriony i płody ludzkie mają więc nie tylko prawo do rozwoju i życia ${ }^{15}$, ale też podmiotowe, niezbywalne prawo do „niereifikowania” ich przez

\footnotetext{
${ }^{13}$ Cfr. D. W. Winnicott, Dal luogo delie origini, Milano 1990, s. 125-130.

${ }^{14} \mathrm{Cfr}$. Pontificia Academia Pro Vita, Genitorialità e nuove tecnologie riproduttive. Considerazioni antropologiche, w: http://www. Academiavita.org/template.jsp?sez=Publicazioni\&pag=...

${ }^{15}$ Cfr. A. Baldassarre, I diritti inviolabili del concepito, w: A. Loiodice - M. Vari, Giovanni Paolo II. Le vie delia giustizia. Itinerari per il terzo millennio, Bari 2004, s. 343-344; T. Di Gioia,
} 
rodziców, przynajmniej w takiej mierze, $\mathrm{w}$ jakiej naruszałoby to ich prawo do bycia sobą ${ }^{16} \mathrm{i}$ bycia szczęśliwym.

Jest to więc zagadnienie o wiele bardziej skomplikowane niż zwykłe uznanie podmiotowości prawnej embrionu lub płodu ludzkiego, gdyż nasza rzeczywistość jest gmatwaniną licznych kontrowersji. Przykładowo, po urodzeniu dziecka cała medycyna i biotechnologie wkraczają do akcji, czasami stosując wręcz uporczywą terapię w obronie prawa do życia nawet najbardziej pokrzywdzonych przez los noworodków, które bez zaangażowania całej wiedzy medycznej i środków nie przeżyłyby nawet kilku dni. Wszak dzieciobójstwo jest przestępstwem, a przecież jeszcze przed narodzeniem tych samych embrionów i płodów nie chroni się je nie tylko przed aborcją zamierzona, prawnie dozwolona, ale nawet przed nieuczciwym handlem ich tkankami ani nawet przed nieodpowiedzialnym postępowaniem ich biologicznych rodziców. Stąd noworodek może umrzeć z powodu głodu narkotykowego jego matki, która nie ponosi za to żadnej odpowiedzialności. W żaden sposób nie jest to odbierane jako zbrodnia dzieciobójstwa. A skoro prawo pozytywne nie dopuszcza handlu własnymi organami, dziećmi (lub ich częściami), to dlaczego sprzedaż lub odstąpienie komórek jajowych lub spermy nie jest przestępstwem?

Problem nie polega na przyznaniu pierwszeństwa prawu do życia przed prawem do rodzicielstwa. Różnica wynika z symbolicznej wartości przypisywanej rodzącemu się życiu nasciturusa. Uznanie tej wartości wpierw jest aktem kulturowym i społecznym, zanim stanie się subiektywnym przekonaniem typu etycznego, ideologicznego czy religijnego jakiejś osoby. Jednakże to uznanie (nawet jeżeli często dwuznaczne i kontrowersyjne) związane jest z bardziej ogólną koncepcją świętości życia ${ }^{17}$, charakteryzującej konkretne historyczne i kulturowe formy religijności ${ }^{18}$. I odwrotnie, prawo do manipulacji genetycznej, której celem jest reprodukcja życia ludzkiego, jest negacją jakiejkolwiek sakralności. Jest to podstawowe założenie koncepcji wartości życia, które przeciwstawia ekstremalny „laicyzm” etyczny obecnych czasów zarówno deklarowanym i pozytywistycznym postawom moralnym różnych religii, jak i wciąż odnawiającym się „odczuciom religijnym” przejawiającym się w różnych formach świeckości.

Il diritto alla vita come presupposto di ogni diritto fondamentale e come interesse primario superindividuale, w: A. Loiodice, M. Vari, Giovanni Paolo II..., s. 349-350.

${ }^{16}$ Cfr. S. Pollo, Quale argomentazione per le scelte riproduttive?, Bioetica 2 (2000), s. 304-318.

${ }^{17} \mathrm{Cfr}$. L. Ciccone, 30 anni dalia pubblicazione dell'enciclica Humanae vitae, Familia et vita 5 (2000) 2, s. 85-106.

${ }^{18} \mathrm{Już}$ w czasach historycznych, przy ekstremalnym braku poszanowania praw człowieka w postaci usankcjonowania tortur zarówno kobiet, jak i mężczyzn istniały (dwuznaczne i kontrowersyjne) formy poszanowania życia, przejawiające się w zakazie wykonywania kary śmierci na kobiecie oczekującej dziecka. 


\section{Syndrom Geppetto}

Wydaje się, że społeczeństwo nie jest w pełni świadome głębokich zmian kulturowych wywołanych coraz bardziej wyszukanymi metodami biomedycznymi. Nie wydaje się, aby pragnienie rodziców zaprojektowania nowego życia, nawet w minimalnym stopniu odbierane było w społeczeństwie jako nadużycie. A jednak w tego typu działaniach rodziców dostrzega się pewną formę ukrytej przed nami samymi przemocy. Jest to przemoc „subtelna”, długofalowa, warunkująca całość późniejszych relacji łączących rodzica i dziecko, silnie oddziałujących wychowawczo na cały przyszły proces wzrastania. Wydaje się więc, że rosnące możliwości ingerowania $\mathrm{w}$ biologiczne procesy zapłodnienia sprzyjają i ujawniają się w osobistych doświadczeniach, w których dziecko staje się coraz bardziej ,,projektem” rodziców ${ }^{19}$, a coraz mniej podmiotem osobliwego „spotkania” dwóch pokoleń.

Narodziny człowieka w swej egzystencjalnej realizacji, stają się „produktem” woli i działania rodziców. Dziecko nie jest już więc „darem” lub „obietnicą”, efektem bożego błogosławieństwa ani niepokojącą zapowiedzią zbliżającej się starości, przeznaczenia, ale rezultatem inwestycji sił, osobistych starań; jest „wynagradzane” materialnie i moralnie przez współtworzących rodziców i „gwarantowane” przez naukę, oferującą nieograniczone możliwości kontrolowania rzeczywistości. Stajemy się więc świadkami rzeczywistej reifikacji dziecka, które można zaprogramować i nabyć. Urzeczywistnieniem tego pragnienia jest bajkowa postać Mistrza Geppetto, który chciał stworzyć niezwykłą kukiełkę, która zaspokoiłaby jego potrzeby. Człowiek jednak początkowo nie wziął pod uwagę już istniejącego potencjału witalności w kawałku niezwykłego drewna, właśnie dlatego, że kukiełka miała być „produktem". Potencjału, który stał się ograniczeniem dla projektu i umiejętności technicznych stolarza. W rezultacie perypetie kukiełki uczyniły z Geppetto respektującego indywidualność ,dziecka” rodzica, a Pinokio stał się prawdziwym dzieckiem, ale dopiero wtedy, kiedy wzajemnie uznali siebie za podmioty spotkania. To Geppetto, jako pierwszy, musiał uznać indywidualność Pinokia i odstapić od swego początkowego projektu, a dopiero później protagonista bajki porzucił postać z drewna jako symbol całkowitej zależności.

To, co można by nazwać „syndromem Geppetto”, polega właśnie na powracającej pokusie każdego z nas stworzenia sobie wspaniałej kukiełki, która towarzyszyłaby nam przez całe życie, która spełniałaby nasze oczekiwania i potwierdziłaby naszą osobistą tożsamość. Wyraża ona całkowite identyfikowanie życia rodzica z życiem dziecka. Wychodzi się z tego chyba jedynie poprzez uzdrawiające rozczarowanie, jakiego doznał Geppetto. To wspaniałe dziecko zawsze będzie się buntować i popychać rodziców w nieobranym przez nich kierunku. Aby stać się rodzicem, trzeba

${ }^{19}$ Cfr. S. Pollo, dz. cyt., s. 304-318; Z. Grabczak, Wybrane problemy etyczne diagnostyki prenatalnej, w: J. Nagorny, P. Kieniewicz (red.), Geny - wolność zapisana? Meandry wspótczesnej genetyki. Przestanie moralne Kościoła, Lublin 2005, s. 133-162. 
zrezygnować ze „wspaniałej kukiełki” i przyjąć ryzyko całkowitej akceptacji niepokojącej tajemnicy przeznaczenia dziecka.

Jeżeli dziecko nabywa wartości «projektu» rodzica (lub rodziców), również jego edukacja będzie odpowiedzią na zaprogramowaną inwestycję, włożoną energię i pieniądze. Także cały późniejszy proces wychowawczy i edukacyjny będzie miał charakter finezyjnej przemocy, która prędzej czy później spotka się z podobną odpowiedzią. Będzie to rewindykacja dziecka-kukiełki własnej autonomii egzystencjalnej. Hasło „Moje życie należy do mnie!” to najczęściej spotykana współczesna forma protestu nastolatków.

\section{Sindrome Geppetto. Evoluzione di genitorieta' nelle societa' economicamente avanzate}

(Riassunto)

Fra le tante rivoluzioni culturali della nostra epoca appare contrassegnata, una riguarda la genitorialità. Questa trasformazione è la conseguenza di enorme potere acquisito dalla ricerca e dalla biotecnologia sulla riproduzione della vita che nel modo evidente trasforma i costumi radicati nella società ma soprattutto modifica le rappresentazioni collettive della generatività umana.

Fino a poco tempo fa la nostra cultura e la tradizione giuridica occidentale hanno distinto la genitorialità biologica da quella legale attribuendo un primato a quella biologica che costituiva un principio di certezza giuridica decivivo per l'identità sociale del nuovo nato. L'avvento dei metodi artificiali di riproduzione ha determinato la separazione fra "naturale" e biologico e stravolge la nozione di genitorialità biologica come genitorialità naturale. Così anche la nozione di padre e di madre biologico si riferisce ora a qualcosa di ben diverso da ciò che si è sempre indicato con questo termine. Quindi, abbiamo oggi madri naturali ma non biologiche e padri e madri biologici (i donatori) non naturali, che possono essere del tutto ignoti ai figli, alle donne gestanti e partorienti. In questa ottica, se il figlio assume il valore di un progetto, anche la sua educazione dovrà essere subordinata a un programma di sentimenti, energie e denaro. Di conseguenza tutta l'azione educativa non potrà sottrarsi ad un sottile violenza dell'adulto. A questa violenza, prima o poi, si contrapporrà un'altra inevitabile risposta violenta, con cui il figlio reclamerà la propria autonomia esistenziale. 